\title{
PENERAPAN PEMBELAJARAN SENI BUDAYA MELALUI DARING SECARA KREATIF DAN INOVATIF DI MASA PANDEMI COVID-19
}

\author{
Annisa Azzahra* \\ E-mail: annisa.azzahra6199@ student.unri.ac.id \\ *Program Studi Pendidikan Bahasa Dan Sastra \\ Indonesia, Universitas Riau
}

\section{Pengantar}

Pendidikan merupakan suatu kegiatan ataupun aktivitas yang berperan sangat penting dalam suatu kehidupan guna meningkatkan daya pikir, keterampilan, kecerdasan, bakat seseorang, dan menjadikan seseorangg bertanggung jawab terhadap sekitar. Pendidikan wajib dilakukan oleh masyarakat yang bertujuan untuk menumbuh-kembangkan calon penegak negara agar tetap sukses dan terus maju dalam beraktivitas. Kegiatan mengajar dalam suatu pendidikan tidak hanya dilakukan di lingkup sekolah saja tetapi juga dapat dilakukan di luar sekolah.

Dalam pendidikan terdapat suatu pembelajaran yang akan dilakukan oleh para guru yang ada di seluruh sekolah. Saat ini masih banyak kondisi di lapangan yang kurang aktif maupun terdapat kendala dalam melakukan suatu proses pembelajaran dikarenakan beberapa masalah yang terjadi. Misalnya saja dikarenakan pandemic saat ini yang sangat memiliki dampak terhadap suatu aktivitas seluruh dunia khususnya Indonesia. Akibatnya, pendidikan di Indonesia memberhentikan pembelajaran secara tatap muka (konvensional) dan berganti dengan pembelajaran secara daring (online), selain itu juga kendala seperti kualitas guru dan sarana prasarana pembelajaran, serta kemungkinan besar jaringan internet yang tidak stabil.

Dengan begitu, suatu tantangan bagi seluruh guru yang ada di Indonesia dalam melakukan penerapan sistem yang baru dan harus mengikuti perintah 
pemerintah yakni dengan pembelajaran daring tersebut. Menurut R. Gilang K. (2020:11) menyatakan bahwa pengertian pembelajaran merupakan suatu proses yang terdiri dari kombinasi dua aspek yaitu, belajar tertuju kepada apa yang harus dilakukan oleh siswa, mengajar berorientasi pada apa yang harus dilakukan oleh guru sebagai pemberi pelajaran adalah suatu kegiatan belajar mengajar yang didalamnya terdapat interaksi positif antara guru dengan siswa dengan menggunakan segala potensi dan sumber yang ada untuk menciptakan kondisi belajar yang aktif dan menyenangkan. Pembelajaran daring merupakan suatu pembelajaran yang dilakukan secara online (tidak langsung) yang menggunakan jaringan internet ataupun platform yang telah tersedia seperti Google Meet, Zoom Meeting, Whatsapp, Telegram, dan lain sebagainya.

Salah satu pembelajaran yang ada di seluruh sekolah yaitu seni budaya. Seni budaya merupakan pendidikan yang berbasis budaya yang menampilkan suatu karya dari peserta didik dengan berbagai keterampilan, inovasi, maupun kreativitas mereka. Pembelajaran seni budaya secara daring harus dilakukan dengan berbagai ketersediaan platform yang ada, sehingga dalam melaksanakan pembelajaran di masa pandemic Covid-19 dapat terus berjalan tanpa adanya hambatan.

\section{Tindakan yang Dilakukan}

\section{Mempersiapkan pendidik dan peserta didik}

Guru merupakan seseorang yang dapat dijadikan pedoman bagi peserta didiknya agar dapat dicontoh oleh tiap orang hingga masyarakat lainnya. Peran seorang guru sangat diperlukan oleh lingkungan sekitar sebagai pendidik pada anak-anak generasi kedepannya. Tugas guru tidak hanya mengajar, mendidik dan melatih peserta didik, tetapi juga harus bisa mengembangkan segala hal yang bersangkutan dengan kemampuan dari peserta didik dan nilai kehidupan yang peserta didik miliki. Sebagai seorang pendidik atau guru harus bisa mengembangkan potensi kreativitas, inovasi serta keterampilan peserta didik dalam mengetahui ilmu pengetahuan. Pendidik wajib menyampaikan pelajaran yang menarik dan 
asyik bagi minat peserta didik agar dapat diserap ilmunya oleh mereka dengan begitu mudah walaupun dengan pembelajaran daring saat ini. Pendidik juga harus mengetahui situasi peserta didiknya agar dapat memberikan kondisi yang baik saat melakukan pembelajaran, mengetahui karakteristik peserta didik agar dapat memudahkan pendidik dalam menentukan strategi yang digunakan, pendidik wajib memiliki rencana pelaksanaan pembelajaran agar pembelajaran dapat berjalan dengan lancar, efektif dan efisien, serta peserta didik dapat menangkap pelajaran yang telah diberikan oleh guru/pendidik tersebut. Pendidik wajib memberikan arahan yang terbaik kepada peserta didik agar memberikan kemudahan dalam melaksanakan pembelajaran dan peserta dapat memperoleh ilmu dengan baik.

\section{Diklat pembelajaran daring}

Pembelajaran daring yang dilakukan oleh pendidik maupun peserta didik saat adanya pandemic Covid-19 sudah berbeda dengan sebelumnya, dikarenakan pembatasan protocol kesehatan, sehingga mau tidak mau pembelajaran jarah jauh harus dilakukan baik dari tingkat SD, SMP, SMA, hingga perkuliahan. Sehingga pendidik pun juga harus bersedia dengan pelaksanaan sistem pembelajaran daring tersebut.

Pelaksanaan pembelajaran daring (jarak jauh) dapat menggunakan aplikasi-aplikasi atau situs web yang tersedia, mulai dari Google Classroom, Google Meet, Zoom Meeting, Whatsapp, Telegram, Youtube, dan lain sebagainya. Pendidik mengaharapkan setelah dilakukannya diklat pembelajaran daring ini maka peserta didik dan pendidik dapat terbiasa dengan sistem baru ini serta kedepannya mampu mengembangkan diri dalam pengelolaan pembelajaran jarak jauh (daring). Tujuan dilakukan pembelajaran daring tersebut adalah memberikan wawasan bagi pendidik mengenai metode pembelajaran jarak jauh secara daring, memberikan kemampuan bagi para pendidik untuk dapat menguasai dan menggunakan perangkat lunak aplikasi pendukung proses belajar mengajar secara daring.

\section{Mengirimkan link video pembelajaran pembuatan karya seni}


Pendidik dalam memberikan pembelajaran secara daring juga dapat melalui edukasi berbasis video, yang dimana lebih memudahkan oleh peserta didik dalam menangkap berbagai macam materi dalam video tersebut. Video yang diberi oleh pendidik harus dapat mudah dipahami, tidak bertele-tele, kreatif, inovatif, dan lain sebagainya yang tujuannya agar peserta didik tertarik dengan video edukasi seni budaya tersebut.

Tindakan ini wajib dilakukan oleh pendidik dikarenakan jika hanya bermodalkan dengan pembelajarn biasa maka besar kemungkinan peserta didik mengalami kejenuhan dan kebosanan terhadap materi yang diberikan oleh pendidik tersebut, dengan demikian pengiriman link video pembelajaran pembuatan karya seni ini sangat memiliki pengaruh terhadap sikap peserta didik dalam menanggapi dan memahami materi yang diberikan oleh pendidik.

\section{Sarana Pendukung}

\section{Hp/laptop}

Hp/laptop merupakan alat yang wajib digunakan ketika melakukan pembelajaran secara daring, jika tidak ada alat ini maka pembelajaran tersebut tidak dapat dilaksanakan. Selain itu hp/leptop dapat digunakan dalam melaksanakan berbagai tugas-tugas yang nantinya akan dikirimkan kepada pendidik secara online.

\section{Google classroom}

Google classroom ini dapat memberikan peserta didik dalam memahami materi, karena melalui Google classroom sang pendidik akan membagikan berbagai macam materi yang akan diajarkan, selain itu juga dapat memberikan sebuah video edukasi karya seni kepada peserta didik, pemberian jadwal, dan pengumpulan tugas, serta lain sebagainya.

\section{Google meet/zoom}

Google meet/zoom adalah situs dan aplikasi pembelajaran online (tidak tatap muka) yang sering digunakan oleh guru dalam memberikan materi pada peserta didiknya. Situs/aplikasi ini juga dapat digunakan dalam 
pertemuan secara online. Penggunaannya yaitu dengan melalui berbagi layar kepada peserta didik dapat berupa wajah pendidik dalam melangsungkan pembelajaran, sebuah power point untuk dipresentasikan, maupun membagikan video ke layar pada situs/aplikasi tersebut.

\section{WA/Telegram}

Apliskasi chatting ini dapat digunakan sebagai tempat pengumpulan/pemberian tugas maupun pembelajaran menggunakan Video Call oleh pendidik kepada peserta didik.

\section{Youtube}

Situs ini berfungsi untuk memberikan edukasi yang didapatkan pendidik berupa video kepada peserta didik yang nantinya akan dibagikan oleh mereka untuk dapat dipelajari dan dapat dipraktekkan secara langsung dengan peralatan ataupun perlengkapan yang telah disediakan oleh peserta didik.

\section{Situs terkait pembuatan karya seni}

Berbagai platform akan menyediakan banyak informasi mengenai ilmu pengetahuan, contohnya Youtube. Youtube mempunyai berbagai macam video yang dapat memberikan edukasi oleh para penontonnya dan menjadikan video tersebut sebagai acuan dalam pembuatan suatu karya seni. Tidak hanya Youtube saja yang mampu memberikan suatu edukasi mengenai ilmu pengetahuan, tetapi Google dan bebrapa link yang memiliki sangkutan dalam pembuatan karya seni sangatlah banyak tersedia di jejaring internet, sehingga tidak ada alasan peserta didik tidak mengetahui dalam pembuatan sebuah karya seni.

\section{Kardus}

Kardus merupakan perlengkapan yang penting dalam mempraktekkan karya walaupun pembelajaran dilakukan secara daring tetapi peserta wajib memahami pelajaran yang diberikan oleh pendidik dan juga dapat dipahami melalui berbagai video yang diberikan oleh pendidik agar peserta didik dapat mempraktekkan dengan mudah dikarenakan terdapat tahapan-tahapan dalam mengerjakan sebuah karya seni tersebut. 


\section{Buku gambar}

Buku gambar merupakan hal yang penting agar peserta didik dapat mempraktekkan secara langsung ketika pendidik menjelaskan secara daring melalui berbagai platform yang tersedia saat ini.

\section{Kuota}

Pengisian kuota yang wajib dilakukan oleh pendidik mapun peserta didik agar dapat melaksanakan pembelajaran daring dengan lancar dan mengurangi hambatan pembelajaran yang akan diikuti.

\section{Jaringan}

Jaringan yang baik akan menghasilkan pembelajaran dengan baik, begitu pula sebaliknya jika jaringan kurang baik dapat memberikan dampak negative bagi para pendidik maupun peserta didik dalam menangkap pelajaran yang akan diberikan, sehingga diperlukan jaringan yang terbaik pada saat melangsungkan pembelajaran daring.

\section{Tindakan Solutif}

\section{Google classroom}

Dampak negatif yang diakibatkan pandemic yaitu tidak diperbolehkannya melakukan pembelajaran secara tatap muka, sehingga tindakan solusi tersebut yaitu melakukan dan memberikan edukasi pembelajaran baik materi, video, dan berbagai tugas melalui Google classroom yang telah disiapkan oleh pendidik untuk peserta didik dalam mendapatkan edukasi tersebut.

\section{Whatsapp grup}

Whatsapp grup adalah salah satu tempat berbagi pendapat, saran, dan kritik mengenai pembelajaran daring. Grup yang tersedia juga memberikan berbagai macam informasi mengenai edukasi maupun sistem pembelajaran serta aplikasi/situs apa yang akan digunakan oleh pendidik dan peserta didik nantinya.

\section{Warnet}


Warnet merupakan singkatan dari warung internet yang berguna untuk memberikan fasilitas jaringan internet maupun computer dalam melaksanakan tugas-tugas yang akan diberikan oleh pendidik kepada peserta didik, sehingga jika tidak ada laptop untuk mengerjakan tugas, peserta didik dapat mengerjakan tugas tersebut di Warnet yang telah disediakan pada lingkungan rumah yang terdekat.

\section{Hotspot/wifi gratis}

Hotspot/wifi gratis mudah didapatkan di berbagai tempat, misalnya kafe. Kafe merupakan salah satu lokasi yang sering dikunjungi oleh para peserta didik dalam menggunakan wifi gratis untuk mengerjakan tugas-tugas yang diberikan oleh pendidik. Hotspot juga mudah didapatkan oleh keluarga bahkan teman terdekat yang memiliki kuota banyak.

\section{Buku gambar}

Buku gambar adalah peralatan yang memiliki kegunaan untuk melakukan atau mempraktekkan gambaran yang nantinya disediakan oleh pendidik melalui daring, buku gambar juga merupakan tindakan solusi yang diperlukan dalam pembelajarn daring khususnya pelajaran seni budaya, dikarenakan buku gambar tersebut merupakan hal yang wajib dipunya dan dimiliki oleh peserta didik.

\section{Pemberian sarana pendukung secara gratis}

Sarana pendukung yang perlu diberikan dari sekolah ke peserta didik salah satunya adalah pemberian kuota gratis dalam menjalankan situs/aplikasi penunjang pembelajaran secara daring. Pemberian kuota gratis memberikan dampak positif kepada peserta didik yang kurang mampu karena jika membeli kuota secara pribadi cukup menghabiskan banyak pengeluaran dana. Pemberian kuota gratis merupakan alternatif terbaik dalam melangsungkan pembelajaran secara daring.

\section{Simpulan}

Pendidikan merupakan suatu kegiatan ataupun aktivitas yang berperan sangat penting dalam suatu kehidupan guna meningkatkan daya pikir, 
keterampilan, kecerdasan, bakat seseorang, dan menjadikan seseorangg bertanggung jawab terhadap sekitar. Pembelajaran daring merupakan suatu pembelajaran yang dilakukan secara online (tidak langsung) yang menggunakan jaringan internet ataupun platform yang telah tersedia seperti Google Meet, Zoom Meeting, Whatsapp, Telegram, dan lain sebagainya.

Tindakan yang dilakukan yaitu meliputi persiapan pendidik dan peserta didik, diklat pembelajaran daring, dan pengiriman link video pembelajaran karya seni. Sarana pendukung dalam pembelajaran daring ini yaitu meliputi hp/laptop, Google classroom, Google Meet. Zoom, Whatsapp, Telegram, Youtube, situs terkait pembuatan karya seni, kardus, buku gambar, kuota dan jaringan. Sedangkan tindakan solusi jika terjadi hal-hal yang tidak diinginkan yaitu dengan Google classroom, Whatsapp grup, warnet, hotspot/wifi, buku gambar, serta pemberian sarana pendukung secara gratis seperti pembagian kuota gratis kepada peserta didik.

\section{Referensi}

Amelia, Indana Zulfa, dkk. (2021). Pembelajaran Daring Seni Budaya Di Kelas VIII A4 SMP Negeri 1 Singaraja. Jurnal Pendidikan Seni Ruga Undiksha, Volume 1 Nomor 2, pp.80-90, 2021.

Khair, Muftiya El \& Irdhan Epria Darma Putra. (2021). Pelaksanaan Pembelajaran Seni Budaya Melalui Daring Di SMP Negeri 26 Padang. E-Jurnal Sendratasik, Volume 10 Nomor 2, Hal 31-40.

K., R. Gilang. (2020). Pelaksanaan Pembelajaran Daring di Era Covid-19. Penerbit Lutfi Gilang. Banyumas.

Pelatihan Peningkatan Pengajaran Jarak-Jauh Secara Daring. https://see.telkomuniversity.ac.id/pelatihan-peningkatan-pengajaran-jarakjauh-secara-daring-dalam-menghadapi-pandemi-covid-19-untuk-guruguru-smp-n-25-bandung/ 